\title{
KUALITAS SISTEM INFORMASI, KUALITAS INFORMASI DAN PERCEIVED USEFULNESS TERHADAPKEPUASAN PENGGUNA AKHIR SOFTWARE ANALISIS KREDIT
}

\author{
INFORMATION SYSTEM QUALITY, INFORMATION QUALITY AND PERCEIVED \\ USEFULNESS TO END USER SATISFIED CREDIT ANALYSIS SOFTWARE
}

\author{
Rizky Hermawan Putra' ${ }^{1)}$, Nila Aprila ${ }^{2) *}$, Fenny Marietza ${ }^{3)}$ dan Madani Hatta ${ }^{4)}$ \\ Universitas Bengkulu ${ }^{1,2,3,4)}$ \\ Rizky_herawan@gmail.com ${ }^{1)}$,naprila@unib.ac.id ${ }^{2)}$,fmarietza@unib.ac.id ${ }^{3)}$,mhatta@unib.ac.id ${ }^{4)}$
}

\begin{abstract}
Influence of information system quality, information quality and perceived usefulness on end-user satisfaction credit analysis software aims is to prove the effect of information system quality on end-user satisfaction credit analysis software, to prove the effect of information quality on end user satisfaction credit analysis software, to prove the effect of perceived usefulness on end user satisfaction credit analysis software, and last to prove the effect of system quality, information quality and perceived usefulness together on end-user satisfaction credit analysis software at PT. Bank Rakyat Indonesia, Tbk Bengkulu Branch. The data analysis method used is multiple linear regression analysis. Hypothesis testing obtained results are the quality of the information system has been proven to affect the satisfaction of end users of credit analysis software at PT. Bank Rakyat Indonesia, Tbk Bengkulu Branch. This means that LAS applications can increase data processing capacity, have a high-security system, have good data correction facilities. The quality of information has been proven to affect the satisfaction of end users of credit analysis software at PT. Bank Rakyat Indonesia, Tbk Bengkulu Branch, meaning LAS software can increase user satisfaction because the credit analysis conducted can produce accurate, reliable, timely, and relevant data. And the last result is Perceived usefulness is proven to affect the satisfaction of end users of credit analysis software at PT. Bank Rakyat Indonesia, Tbk Bengkulu Branch, meaning that the LAS application is very helpful in completing the analysis quickly, the LAS application is able to increase work effectiveness and the LAS application makes it easier for employees to complete work so as to increase user satisfaction.
\end{abstract}

Keywords: Information System Quality, System Quality, User Satisfaction

\begin{abstract}
ABSTRAK
Pengaruh kualitas sistem informasi, kualitas informasi dan kegunaan yang dirasakan pada perangkat lunak analisis kredit kepuasan pengguna akhir bertujuan untuk membuktikan efek kualitas sistem informasi pada perangkat lunak analisis kredit kepuasan pengguna akhir, untuk membuktikan efek kualitas informasi pada perangkat lunak analisis kredit kepuasan pengguna akhir, untuk membuktikan efek kegunaan yang dirasakan pada perangkat lunak analisis kredit kepuasan pengguna akhir, dan terakhir untuk membuktikan efek kualitas sistem, kualitas informasi dan kegunaan yang dirasakan bersama-sama pada perangkat lunak analisis kredit kepuasan pengguna akhir di PT. Bank Rakyat Indonesia, Tbk Cabang Bengkulu. Metode analisis data yang digunakan adalah beberapa analisis regresi linear. Pengujian hipotesis yang diperoleh hasil adalah kualitas sistem informasi telah terbukti mempengaruhi kepuasan pengguna akhir perangkat lunak analisis kredit di PT. Bank Rakyat Indonesia, Tbk Cabang Bengkulu. Ini berarti bahwa aplikasi LAS dapat meningkatkan kapasitas pemrosesan data, memiliki sistem keamanan yang tinggi, memiliki fasilitas koreksi data yang baik. Kualitas informasi telah terbukti mempengaruhi kepuasan pengguna akhir perangkat lunak analisis kredit di PT. Bank Rakyat Indonesia, Tbk Cabang Bengkulu, artinya software LAS dapat meningkatkan kepuasan pengguna karena analisis kredit yang dilakukan dapat menghasilkan data yang akurat, andal, tepat waktu dan relevan. Dan hasil terakhir dirasakan kegunaannya terbukti mempengaruhi kepuasan pengguna akhir perangkat lunak analisis kredit di PT. Bank Rakyat Indonesia, Tbk Cabang Bengkulu, artinya aplikasi LAS sangat membantu dalam menyelesaikan analisis dengan cepat, aplikasi LAS mampu meningkatkan efektivitas kerja dan aplikasi LAS memudahkan karyawan untuk menyelesaikan pekerjaan sehingga dapat meningkatkan kepuasan pengguna.
\end{abstract}

Keywords: Kualitas informasi sistem, Kualitas sistem, Kepuasan pegguna 
*Corresponding author

\section{PENDAHULUAN}

Penggunaan sistem informasi akuntansi dalam perusahaan perbankan ini meningkatkan efektivitas dalam penyajian laporan keuangan, khususnya dalam mengolah data transaksi nasabah perbankan. Karena penggunaan sistem informasi teknologi dalam perusahaan perbankan dibutuhkan untuk mencatat transaksi nasabah yang berlangsung setiap hari, baik transaksi secara offline maupun online. Masalah yang biasanya terjadi dalam pemakaian paket sistem informasi adalah tidak kompatibelnya sistem dengan proses bisnis dan informasi yang diperlukan organisasi (Janson dan Subramanian, 1996; Lucas, et al, 1998). Ketidaksesuaian antara software aplikasi dengan proses bisnis dapat menimbulkan masalah signifikan bagi pemakai. Jika sistem informasi tidak dimanfaatkan secara maksimal atau sistem informasi kurang mampu memberikan hasil yang diharapkan maka akan berdampak pada organisasi perusahaan secara keseluruhan.

Faktor-faktor yang mempengaruhi dalam penggunaan sistem informasi teknologi pada perusahaan perbankan meliputi kualitas sistem informasi, kualitas informasi, perceived usefulness, dan kepuasan pengguna sistem informasi. Kualitas sistem informasi merupakan sistem informasi teknologi berbasis aplikasi yang digunakan dalam memproses data transaksi nasabah (Jogiyanto, 2007). Kualitas sistem informasi memperlihatkan bahwa jika pengguna sistem informasi merasa bahwa menggunakan sistem tersebut mudah, pengguna tidak memerlukan effort banyak untuk menggunakannya, sehingga mereka akan lebih banyak waktu untuk mengerjakan hal lain yang kemungkinan akan meningkatkan kinerja mereka secara keseluruhan. Hasil penelitian yang diperoleh DeLone dan McLean (1992), Almutairi dan Subramanian (2005), serta Livari (2005) menunjukkan bahwa kualitas sistem informasi berpengaruh positif terhadap kepuasan penggunanya. Semakin tinggi kualitas informasi yang dihasilkan suatu sistem informasi, akan semakin meningkatkan kepuasan pengguna (DeLone dan McLean, 1992). Pendapat ini didukung hasil penelitian Almutairi dan Subramanian (2005). Apabila pengguna akhir sistem informasi percaya bahwa kualitas informasi yang dihasilkan dari suatu sistem informasi adalah baik, maka pengguna akhir akan merasakan kepuasan dalam menggunakan sistem informasi tersebut.

Davis et al. (1989) mendefinisikan kemanfaatan (usefulness) sebagai suatu tingkatan dimana seseorang percaya bahwa penggunaan suatu subyek tertentu akan dapat meningkatkan prestasi kerja orang tersebut. Perceived usefulness didefinisikan sebagai sejauh mana seseorang percaya bahwa menggunakan suatu teknologi akan meningkatkan kinerja pekerjaanya. Perceived usefulness merupakan suatu kepercayaan tentang proses pengambilan keputusan, jika seseorang merasa percaya bahwa sistem informasi berguna maka dia akan menggunakannya. Sebaliknya jika seseorang merasa percaya bahwa sistem informasi kurang bergunaa maka dia tidak akan menggunakannya (Jogiyanto, 2007). Sehingga dari definisi tersebut dapat diartikan bahwa kemanfaatan dari penggunaan komputer dapat meningkatkan kinerja, dan prestasi kerja orang yang menggunakannya. Rai et al. (2002) meneliti hubungan antara perceived usefulness dengan user satisfaction, hasil penelitiannya secara keseluruhan menunjukkan perceived usefulness berpengaruh terhadap user satisfaction.

Jika pemakai merasa tidak puas dengan software yang digunakan, mereka akan mencari cara agar sistem tersebut tidak lagi digunakan. EUCS (End User Computer satisfaction) dapat digunakan sebagai sinyal bagi manajemen untuk mengatasi kesulitan dan ketidaksesuaian ini. Seddon (1997) menyatakan bahwa dengan mengatasi kelemahan pengukuran menjadi lebih baik, kepuasan pengguna akhir dapat digunakan untuk mengukur keuntungan atau keberhasilan software akuntansi yang digunakan perusahaan. (Istianingsih dan Wijanto, 2008). DeLone dan McLean (1992) mengungkapkan sebuah model kesuksesan sistem informasi yang dikembangkan oleh mereka sendiri yang mencakup kualitas sistem, kualitas informasi, kegunaan (penggunaan nyata), kepuasan pemakai, dampak individu, dan dampak organisasi. Li (1997) menyatakan bahwa faktor terpenting yang mengindikasikan keberhasilan sistem informasi antara lain adalah tingkat akurasi output, 
reliabilitas output, kepercayaan pemakai terhadap sistem, dan timeliness dari output (Istianingsih dan Wijanto, 2008).

Objek penelitian ini adalah PT. Bank Rakyat Indonesia, Tbk cabang Bengkulu, alasan pemilihan PT. Bank Rakyat Indonesia, Tbk karena merupakan salah satu bank terbesar milik pemerintah. Menurut Forbes pada sebuah berita online mengatakan "PT Bank Rakyat Indonesia (Persero) Tbk. dinobatkan sebagai perusahaan nasional yang paling profitable oleh Forbes Internasional, dari 10 perusahaan Indonesia yang masuk ke dalam 2.000 perusahaan paling untung di dunia, Bank BRI di posisi teratas. Fakta tersebutlah yang menjadi alasan utama dalam pemilihan sasaran dilakukannya penelitian. Istianingsih dan Wijanto (2008) melakukan penelitian untuk menguji pengaruh kualitas sistem, kualitas informasi dan perceive usefulness terhadap tingkat kepuasan pengguna software akuntansi pada berbagai perusahaan yang ada di Indonesia yang telah menerapkan sistem informasi akuntansi berbasis komputer. Hasilnya menunjukkan bahwa semua varibel tersebut di atas berpengaruh positif secara signifikan terhadap tingkat kepuasan pengguna software akuntansi. Mulyono (2008) juga melakukan penelitian untuk menguji kualitas sistem dan kualitas informasi terhadap kepuasan pemakai pada SIKD di Malang dan Batu. Hasilnya menunjukkan bahwa kualitas informasi dan kualitas sistem berpengaruh positif signifikan terhadap kepuasan pengguna. Istianingsih dan Utami (2009) mendukung hasil penelitian Mulyono dan Istianingsih di atas. Penelitiannya dilakukan pada berbagai perusahaan yang ada di Indonesia. Variabel yang diuji adalah kualitas layanan,kualitas informasi, dan kualitas sistem informasi terhadap kepuasan pengguna dan menguji pengaruh kepuasan pengguna terhadap kinerja individu. Hasilnya menunjukkan bahwa variabel kualitas layanan, kualitas informasi, dan kualitas sistem informasi tersebut berpengaruh positif signifikan terhadap kepuasan pengguna dan kepuasan pengguna berpengaruh positif signifikan terhadap kinerja individu Berangkat dari adanya perbedaan hasil penelitian-penelitian terdahulu, penelitian ini kembali menguji pengaruh kualitas sistem informasi, kualitas informasi, dan perceive usefulness terhadap kepuasan pengguna software analisis kredit pada PT. Bank Rakyat Indonesia, Tbk Cabang Bengkulu.

Pada saat ini aplikasi-aplikasi yang digunakan dalam sistem kredit BRI unit adalah aplikasi LAS (Loan Approval Sistem) fungsinya untuk ngimput pinjaman dari nasabah, BRI Checking fungsinya adalah pencarian data debitur, BI Checking fungsinya adalah mengecek data debitur. Lampiran-lampiran yang digunakan yaitu: Surat Keterangan Permohonan Pinjaman (SKPP), Laporan Kunjungan Nasabah (LKN), Surat Penawaran Keputusan Kredit (SPPK), Formulir Review Dokumen, Formulir Pengawasan Paket, Offering Letter (OL) serta Intruksi Pencairan kredit (IPK). Keuntungan penggunaan aplikasi LAS (Loan Approval Sistem) bagi Bank BRI adalah dapat menghasilkan sebuah keputusan yang lebih konsisten, pemahaman yang lebih mendalam atas profil.karakteristik risiko calon nasabah dengan menggunakan scorecard, meningkatkan kontrol dari user/pemakai, mengurangi biaya underwriting, menciptakan pengumpulan data yang komprehensif. Adapun manfaat dari penggunaan aplikasi LAS (Loan Approval Sistem) adalah meningkatkan produktifitas Account Officer (AO), karena proses kredit menjadi lebih cepat dan terukur, risk analisis lebih baik karena dilakukan dengan analsaisi standard yaitu rating system, kapasitas putusan kredit dapat diketahui lebih cepat sehingga pelayanan proses kredit menjadi lebih baik, biaya transaksi lebih renda, monitoring AO lebih baik, peningkatan efisiensi proses bisnis melalui otomasi proses, kemudahan dalam pemantauan status proses aplikasi pengurangan pekerjaan pemasukan data yang berulang dalam proses kredit. Meskipun banyaknya keuntungan serta manfaat dari aplikasi LAS (Loan Approval Sistem) namun masih banyak ditemukan kelemahan dari program aplikasi LAS (Loan Approval Sistem). Fenomena yang sering ditemui dilapangan saat ini adanya kendala yang dihadapi oleh para pengguna program LAS (Loan Approval Sistem) pada PT. Bank Rakyat Indonesia, Tbk cabang Bengkulu. Berdasarkan wawancara yang dilakukan dengan salah satu karyawan PT. Bank Rakyat Indonesia, Tbk cabang Bengkulu sering ditemui permasalahan pada program LAS (Loan Approval Sistem). Masalah tersebut adalah sistem yang tersentralisasi, pemilihan teknologi yang kurang tepat dan kurangnya perencanaan pada implementasi sistem LAS sendiri. 


\section{KERANGKA TEORITIS DAN HIPOTESIS}

\section{Model Kesuksesan Sistem Informasi DeLone dan McLean}

Model kesuksesan sistem informasi DeLone dan McLean (1992) diklasifikasikan ke dalam enam kategori utama, yaitu;

1. Kualitas sistem (system quality), berkaitan dengan evaluasi sistem pengolahan informasi itu sendiri.

2. Kualitas informasi (information quality), berkaitan dengan output sistem informasi.

3. Penggunaan (use), berkaitan dengan penggunaan sistem informasi.

4. Kepuasan pengguna (user satisfaction), berkaitan dengan respon penerima terhadap penggunaan output sistem informasi.

5. Dampak individual (individual impact), merupakan dampak informasi terhadap perilaku penerima.

6. Dampak organisasi (organizational impact), merupakan dampak sistem informasi terhadap kinerja organisasi.

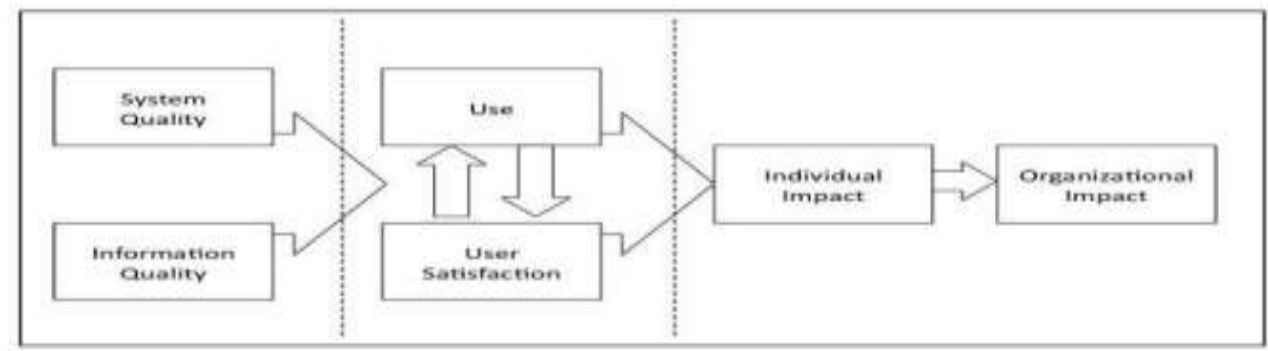

Gambar 1. Model Kesuksesan SI Delone \& Mclean

Sumber: DeLone \& McLean (1992)

Gambar di atas menggambarkan bahwa kesuksesan pengembangan sistem diproyeksi dengan dua variabel yaitu intensitas penggunaan sistem (use) dan kepuasan pengguna sistem informasi yang bersangkutan (user stastifaction). Variabel-variabel yang mempengaruhi kesuksesan sistem informasi adalah kualitas informasi (information quality) sebagai output sistem dan kualitas sistem informasi (system quality) yang bersangkutan. Selanjutnya, variabel intensitas penggunaan sistem juga mempengaruhi kepuasan pengguna sistem informasi yang bersangkutan. Kepuasan dan penggunaan akan memberikan dampak terhadap kinerja individu dan pada akhirnya kinerja organisasi.

\section{End User Computing Satisfaction (EUCS)}

Doll dan Torkzadeh (1988) mengembangkan suatu model yang digunakan untuk mengukur kepuasan pengguna akhir komputer. Mereka mengembangkan instrumen pengukur kepuasan yaitu instrumen EUCS. EUCS adalah metode untuk mengukur tingkat kepuasan dari pengguna suatu sistem aplikasi dengan membandingkan antara harapan dan kenyataan dari sebuah sistem informasi. Doll dan Torkzadeh mengembangkan instrumen EUCS yang terdiri dari 12 item dengan membandingkan lingkungan pemrosesan data tradisional dengan lingkungan end user computing, yang meliputi lima komponen: isi (content), akurasi (accuracy), bentuk (format), kemudahan (ease) dan ketepatan waktu (timeliness).Model evaluasi yang dikembangkan oleh Doll dan Torkzadeh (1988) lebih menekankan kepuasan (satisfaction) pengguna akhir terhadap aspek teknologi, dengan menilai isi, keakuratan, format, waktu dan kemudahan penggunaan dari sistem. Model ini telah banyak diujicobakan oleh peneliti lain untuk menguji reliabilitasnya dan hasilnya menunjukkan tidak ada perbedaan bermakna meskipun instrumen ini diterjemahkan dalam berbagai bahasa yang berbeda. Model EUCS digambarkan pada gambar berikut ini: 


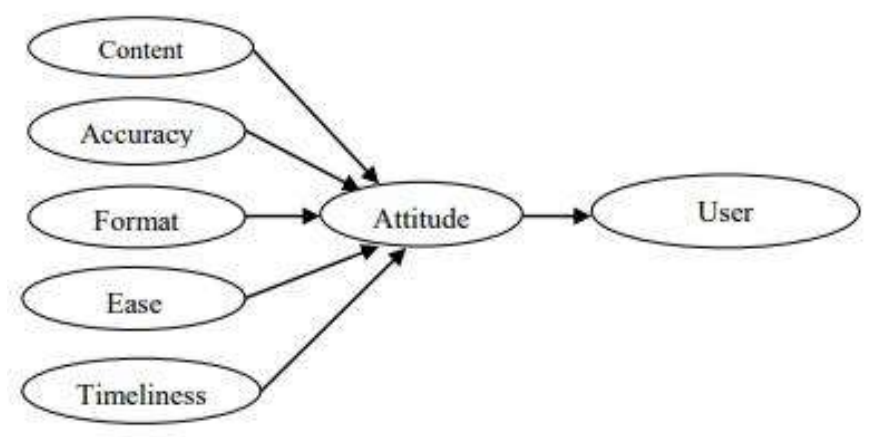

Gambar 2. End User Computing Satisfaction Model Sumber: Doll and Torkzadeh (1988)

\section{Kualitas Sistem Informasi}

Kualitas sistem informasi merupakan karakteristik dari informasi yang melekat mengenai sistem itu sendiri (DeLone dan McLean, 2003. Kualitas sistem informasi juga didefinisikan Davis et al. (1989) dan Chin dan Todd (1995) sebagai perceived ease of use yang merupakan tingkat seberapa besar teknologi komputer dirasakan relatif mudah untuk dipahami dan digunakan. Kualitas sistem berarti kualitas dari kombinasi hardware dan software dalam sistem informasi. Kualitas sistem dalam penelitian ini didefinisikan sebagai kualitas dari software akuntansi. Fokusnya adalah performa dari sistem tersebut, yang merujuk pada seberapa baik kemampuan perangkat keras, perangkat lunak, kebijakan, dan prosedur dari sistem informasi dapat menyediakan informasi bagi kebutuhan pengguna (DeLone dan McLean, 2003).

\section{Kualitas Informasi}

Kualitas informasi adalah tingkat dimana informasi memiliki karakteristik isi, bentuk, dan waktu, yang memberikannya nilai buat para pemakai akhir tertentu (O'Brien, 2009). Kualitas informasi merupakan kualitas output yang berupa informasi yang dihasilkan oleh sistem informasi yang digunakan (Rai et al., 2012). Liu dan Arnett (2010) menyatakan bahwa informasi dengan kualitas terbaik akan meningkatkan kegunaan persepsian pengguna dan meningkatkan penggunaan sistem informasi. Kualitas informasi juga dapat dilihat dengan adanya potensi menghasilkan informasi yang tidak terbatas baik dalam organisasi maupun luar organisasi.

\section{Perceived Usefulness}

Davis (1989) mendefinisikan kemanfaatan (usefulness) sebagai suatu tingkatan dimana seseorang percaya bahwa penggunaan suatu subyek tertentu akan dapat meningkatkan prestasi kerja orang tersebut. Perceived usefulness didefinisikan sebagai sejauh mana seseorang percaya bahwa menggunakan suatu teknologi akan meningkatkan kinerja pekerjaanya. Definisi diatas mengungkapkan bahwa perceived usefulness merupakan suatu kepercayaan tentang proses pengambilan keputusan. Pengguna sistem informasi yang mempercayai bahwa sistem informasi yang digunakannya bermanfaat, maka dia akan menggunakannya. Sebaliknya, jika pengguna sistem informasi percaya bahwa sistem informasi kurang berguna maka dia tidak akan menggunakannya (Jogiyanto, 2007).

\section{Kepuasan Pengguna (User Satisfaction)}

Kepuasan penggunaan informasi menurut Bayley (1983) dalam Al Ghatani (1999) merupakan sikap multidimensional dari pengguna terhadap aspek-aspek yang berbeda dalam sistem infomasi. Sedangkan menurut Ives, et. Al. (1983) dalam Al Ghatani (1999) kepuasan 
penggunaan informasi adalah seberapa jauh informasi yang disediakan untuk memenuhi kebutuhan informasi yang mereka butuhkan. Dari pengertian di atas dapat disimpulkan bahwa kepuasan pengguna menggambarkan keselarasan antara harapan seseorang dan hasil yang diperoleh dengan adanya suatu sistem dimana tempat orang tersebut turut berpartisipasi dalam pengembangannya.

\section{Pengembangan Hipotesis}

Kualitas sistem informasi merupakan karakteristik dari informasi yang melekat mengenai sistem itu sendiri (DeLone dan McLean, 1992. DeLone dan McLean (1992) menemukan bahwa kualitas sistem (system quality) dapat mempengaruhi kepuasan pengguna (user satisfaction). Model kesuksesan DeLone dan McLean mengemukakan kualitas sistem mengukur kesuksesan teknikal, kualitas informasi mengukur kesuksesan semantik, dan pengunaan sistem, kepuasan pengguna, individual impact dan organizational impact mengukur kesuksesan keefektivan. Hal ini menggambarkan bahwa jika pemakai sistem informasi merasa bahwa menggunakan sistem tersebut mudah dan efisien, mereka tidak memerlukan upaya yang banyak untuk menggunakannya, sehingga mereka akan lebih banyak waktu untuk mengerjakan hal lain yang kemungkinan akan meningkatkan kinerja mereka secara keseluruhan. Juga para pengguna mampu melakukan tugasnya secepat mungkin dan seefisien mungkin. Penelitian ini didukung dengan penelitian yang dilakukan oleh Rukmiati (2016), Salam (2014) dan Pamungkas (2017), menunjukkan adanya pengaruh yang positif antara kualitas sistem informasi dengan perceived usefulness. Berdasarkan penelitian-penelitian tersebut diatas dapat dikatakan bahwa jika pemakai sistem informasi percaya bahwa jika kualitas sistem informasi yang digunakan adalah baik, maka mereka akan merasa puas menggunakan sistem tersebut. Sehingga hipotesis pertama dalam penelitian ini adalah semakin tinggi kualitas informasi yang dihasilkan oleh software analisis kredit yang digunakan akan meningkatkan kepuasan pengguna berdasarkan persepsi mereka. Berdasarkan pemaparan tersebut hipotesis penelitian yang diajukan adalah sebagai berikut :

$\mathrm{H}_{1}$ : Kualitas sistem informasi berpengaruh positif pada kepuasan pengguna akhir software analisis kredit

Kualitas informasi merupakan kualitas output yang berupa informasi yang dihasilkan oleh sistem informasi yang digunakan (Rai et al., 2002). Kualitas informasi juga dapat dilihat dengan adanya potensi menghasilkan informasi yang tidak terbatas baik dalam organisasi maupun luar organisasi (Barnes et al., 2003). Berdasarkan teori diatas dapat disimpulkan bahwa jika pemakai sistem informasi percaya bahwa jika kualitas informasi yang dihasilkan dari sistem yang digunakan adalah baik, maka mereka akan merasa puas menggunakan sistem tersebut. Apabila pengguna akhir sistem informasi percaya bahwa kualitas informasi yang dihasilkan dari suatu sistem informasi adalah baik, maka pengguna akhir akan merasakan kepuasan dalam menggunakan sistem informasi tersebut. Menurut penelitian Presejo (2016) bahwa kualitas informasi berpengaruh positif dan signifikan terhadap kepuasan penggugna. Hal serupa juga dibuktikan oleh penelitian yang dilakukan oleh Pamungkas (2017) dan Salam (2016) bahwa terdapat pengaruh yang positif antara kualitas informasi dengan kepuasan pengguna. Menurut penelitian DeLone dan McLean (1992), kualitas informasi (information quality) suatu sistem dapat mempengaruhi kepuasan pengguna (user satisfaction). Berdasarkan penelitianpenelitian sebelumnya sehingga hipotesis kedua dalam penelitian ini adalah semakin tinggi kualitas informasi yang dihasilkanoleh software akuntansi yang digunakan akan meningkatkan kepuasan pengguna berdasarkan persepsi mereka. Berdasarkan pemaparan tersebut hipotesis penelitian yang diajukan adalah sebagai berikut :

$\mathrm{H}_{2}$ : Kualitas informasi berpengaruh positif terhadap kepuasan pengguna akhir software analisis kredit 
Menurut Jogiyanto (2007), Perceived usefulness merupakan suatu kepercayaan tentang proses pengambilan keputusan, jika seseorang merasa percaya bahwa sistem informasi berguna maka dia akan menggunakannya. Sebaliknya jika seseorang merasa percaya bahwa sistem informasi kurang berguna maka dia tidak akan menggunakannya. Sehingga dari definisi tersebut dapat diartikan bahwa kemanfaatan dari penggunaan komputer dapat meningkatkan kinerja, dan prestasi kerja orang yang menggunakannya. Hal ini menggambarkan bahwa persepsi kemanfaatan (perceived usefulness). Sehingga dapat dikatakan jika pengguna sistem informasi merasakan manfaat atas sistem yang digunakan, maka mereka akan merasa puas menggunakan sistem tersebut. Hasil penelitian Rukmiati (2016) membuktikan bahwa perceived usefulness berpengaruh positif terhadap kepuasan akhir sistem informasi. Penelitian lain juga dilakukan oleh Pemungkas (2017) dengan hasil antara perceived usefulness memiliki pengaruh positif dan signfikan dengan kepuasan pengguna akhir software akuntansi tetapi tidak mendukung penelitian Salam (2016) bahwa perceived usefulness tidak berpengaruh terhadap kepuasan pengguna akhir Berdasarkan uraian di atas maka hipotesis ketiga dalam penelitian ini adalah semakin tinggi perceived usefulness akan meningkatkan kepuasan pengguna berdasarkan persepsi mereka. Berdasarkan pemaparan tersebut hipotesis penelitian yang diajukan adalah sebagai berikut :

$\mathrm{H}_{3}$ : Perceived usefulness berpengaruh positif terhadap kepuasan pengguna akhir software analisis kredit.

\section{Kerangka Pemikiran} berikut :

Adapun kerangka pemikiran yang digunakan dalam penelitian ini adalah seperti pada gambar

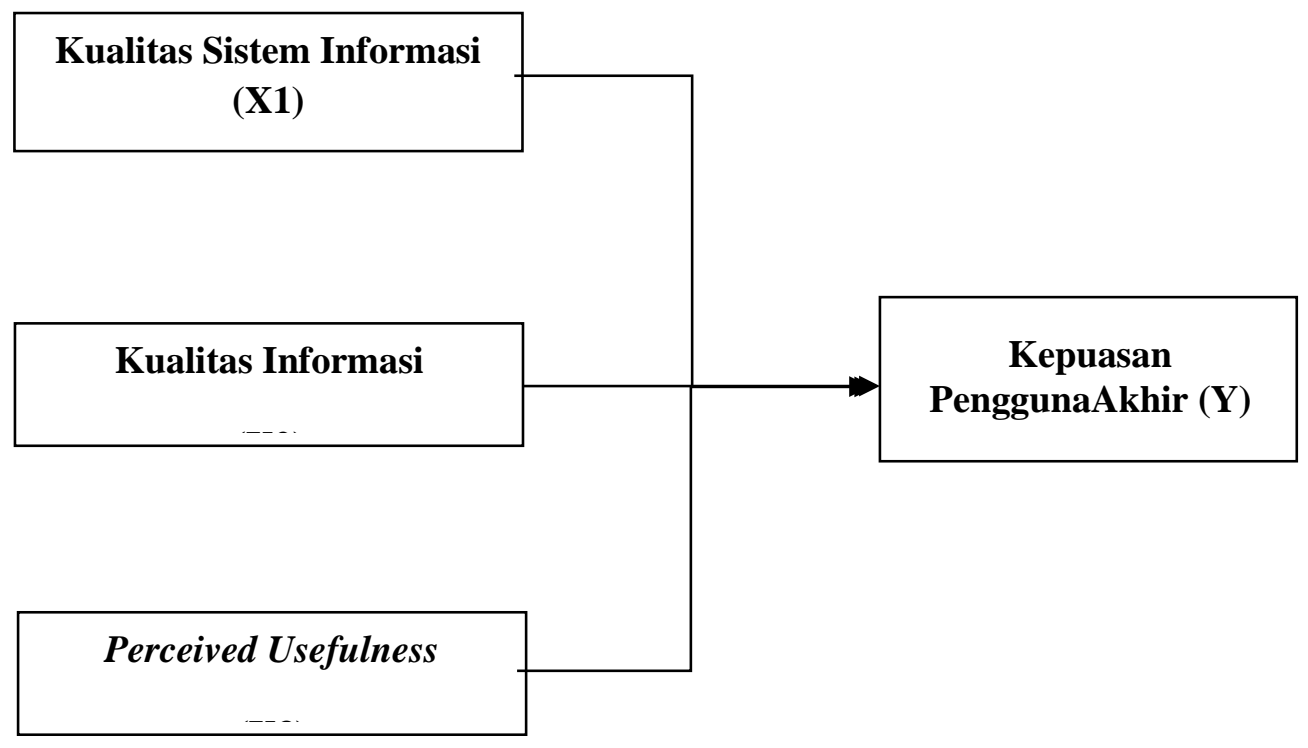

Gambar 3. Kerangka Pemikiran

Berdasarkan kerangka pemikiran diatas dapat dilihat adanya pengaruh dari kualitas sistem, kualitas informasi dan perceived usefulness terhadap kepuasan pengguna akhir software analisis kredit pada PT. Bank Rakyat Indonesia, Tbk Cabang Bengkulu.

\section{METODE PENELITIAN}

\section{Populasi dan Sampel}

Populasi penelitian ini adalah seluruh pengguna aplikasi LAS (Loan Approval Sistem) yang ada di 17 unit PT. Bank Rakyat Indonesia, tbk Cabang Bengkulu yang berjumlah 137 
karyawan. Adapun kriteria pemilihan sampel yang digunakan dalam penelitian ini adalah sebagai berikut :

1. Karyawan PT. Bank Rakyat Indonesia, Tbk cabang Bengkulu yang telah menjadi pegawai tetap.

2. Karyawan PT. Bank Rakyat Indonesia, Tbk cabang Bengkulu yang mengoperasikan aplikasi LAS (Loan Approval Sistem) dan merupakan pengguna akhir dari aplikasi LAS (Loan Approval Sistem)yang disebut dengan mantri.

Berdasarkan kriteria tersebut maka jumlah sampel dalam penelitian ini adalah 115 orang mantri pengguna aplikasi LAS (Loan Approval Sistem) yang ada di 17 unit PT. Bank Rakyat Indonesia, tbk Cabang Bengkulu.

\section{Metode Pengumpulan Data}

Metode pengumpulan data yang digunakan dalam penelitian ini adalah penyebaran kuesioner. Menurut Sugiyono (2013) kuisioner merupakan teknik pengumpulan data yang dilakukan dengan cara memberi seperangkat pertanyaan atau pernyataan tertulis kepada responden untuk dijawab. Kuisioner dalam penelitian ini merupakan daftar pertanyaan yang disebarkan kepada Karyawan pengguna aplikasi LAS (Loan Approval Sistem) yang ada di 17 unit PT. Bank Rakyat Indonesia, tbk Cabang Bengkulu untuk memperoleh data primer. Pertanyaan di dalam kuesioner berupa pertanyaan tertutup, yakni pertanyaan-pertanyaan yang disertai dengan pilihan jawaban. Hal ini dimaksudkan agar memudahkan responden dalam mengisi pertanyaan-pertanyaan yang diajukan.

\section{HASIL PENELITIAN DAN PEMBAHASAN}

\section{Deskripsi Penyebaran Kuesioner}

Pengumpulan data pada penelitian ini dilakukan dengan cara menyebarkan 115 kuesioner secara langsung ke unit PT. Bank Rakyat Indonesia, tbk Cabang Bengkulu. Jumlah kuesioner yang disebarkan dalam penelitian adalah 115 eksemplar sesuai dengan jumlah sampel penelitian. Dari jumlah yang disebarkan tersebut, 112 eksemplar dikembalikan kepada peneliti, sementara 3 eksemplar tidak dikembalikan oleh responden. Setelah dilakukan pengecekan terhadap setiap eksemplar kuesioner dari total kuesioner yang diterima, 109 eksemplar kuesioner yang layak dilakukan analisis, sedangkan sisanya tidak layak karena ada beberapa pertanyaan yang tidak diisi secara lengkap oleh responden.

Tabel 1. Rincian Tingkat Pengembalian Kuesioner

\begin{tabular}{l|c|c}
\hline \multicolumn{1}{c|}{ Rincian } & Jumlah (Eks) & Persentase (\%) \\
\hline Kuesioner yang disebar & 115 & 100 \\
\hline Kuesioner yang dikembali & 112 & 97,39 \\
\hline Kuesioner yang diisi tidak lengkap & 3 & 2,61 \\
\hline Kuesioner yang dapat digunakan (dianalisis) & 109 & 94,78 \\
\hline Sumber $:$ Data diolah 2020
\end{tabular}

Sumber : Data diolah, 2020

\section{Statistik Deskriptif}

Sampel dalam penelitian ini adalah karyawan pengguna aplikasi LAS (Loan Approval Sistem) PT. Bank Rakyat Indonesia, Tbk Cabang Bengkulu yang dikenal dengan mantri, berdasarkan data kuesioner yang terkumpul maka jumlah sampel dalam penelitian ini adalah sebanyak 109 orang. Variabel penelitian terdiri dari 4 variabel yaitu satu variable terikat (kepuasan pengguna akhir), tiga variable bebas yaitu kualitas sistem informasi, kualitas informasi dan perceived usefulness. Deskripsi variable penelitian dapat dilihat pada tabel berikut : 
Tabel 2. Deskriptif Statistik Variabel Penelitian

\begin{tabular}{|c|c|c|c|c|c|c|c|}
\hline & \multicolumn{3}{|c|}{ Kisaran } & \multicolumn{3}{|c|}{ Kisaran } & \multirow{3}{*}{$\begin{array}{c}\text { Std. } \\
\text { Deviation }\end{array}$} \\
\hline & \multicolumn{2}{|c|}{ Teoritis } & \multirow{2}{*}{$\begin{array}{c}\text { Mean } \\
\text { Teoritis }\end{array}$} & \multicolumn{2}{|c|}{ Aktual } & \multirow{2}{*}{$\begin{array}{l}\text { Mean } \\
\text { Aktual }\end{array}$} & \\
\hline Variabel & Min & Max & & Min & Max & & \\
\hline $\begin{array}{l}\text { Kualitas system } \\
\text { Informasi }\end{array}$ & 8 & 40 & 24 & 23 & 37 & 29.76 & 2.718 \\
\hline Kualitas informasi & 6 & 30 & 18 & 18 & 30 & 23.73 & 2.602 \\
\hline Perceived Usefulness & 6 & 30 & 18 & 16 & 28 & 23.28 & 2.182 \\
\hline $\begin{array}{l}\text { Kepuasan Pengguna } \\
\text { Akhir }\end{array}$ & 5 & 25 & 15 & 14 & 24 & 19.24 & 2.063 \\
\hline
\end{tabular}

Sumber : Data diolah, 2020

Pengujian validitas menggunakan teknik validitas konvergen menggunakan explanatory factor analysis (EFA). Menurut Hair et al (2005) angka minimal dari factor loading adalah 0,3, nilai 0,5 adalah cukup sedangkan idealnya adalah 0,7.Dalam melakukan analisis EFA, dianalisis juga nilai Kaiser Meyer Olkin (KMO) Measure of Sampling Adequacy (MSA). Uji KMO ini dilakukan untuk mengetahui apakah semua data yang telah terambil telah cukup untuk difaktorkan. Apabila nilai KMO > 0,60 maka secara keseluruhan model analisis faktor layak (fit) (Hair, 2006). Berdasarkan hasil pengolahan data, diperoleh hasil pengujian nilai KMO-MSA sebagaimana terangkum pada Tabel berikut ini.

Tabel 3 Uji Validitas

\begin{tabular}{|c|c|c|c|c|}
\hline Variabel & Item & Anti Image & Nilai & Keterangan \\
\hline & Pertanyaan & Correlation & KMO & \\
\hline Kualitas & $\mathrm{X} 1.1$ & 0,640 & 0,778 & Valid \\
\hline sistem & $\mathrm{X} 1.2$ & 0,761 & & Nilai KMO dan skor \\
\hline informasi & $\mathrm{X} 1.3$ & 0,891 & & factor loading $>0,5$ \\
\hline \multirow[t]{5}{*}{ (X1) } & $\mathrm{X} 1.4$ & 0,911 & & \\
\hline & $\mathrm{X} 1.5$ & 0,594 & & \\
\hline & X1.6 & 0,809 & & \\
\hline & $\mathrm{X} 1.7$ & 0,792 & & \\
\hline & $\mathrm{X} 1.8$ & 0,763 & & \\
\hline Kualitas & $\mathrm{X} 2.1$ & 0,599 & 0,630 & Valid \\
\hline informasi & $\mathrm{X} 2.1$ & 0,737 & & Nilai KMO dan skor \\
\hline \multirow[t]{4}{*}{ (X2) } & $\mathrm{X} 2.3$ & 0,609 & & factor loading $>0,5$ \\
\hline & X2.4 & 0,824 & & \\
\hline & $\mathrm{X} 2.5$ & 0,764 & & \\
\hline & $\mathrm{X} 2.6$ & 0,734 & & \\
\hline Perceived & $\mathrm{X} 3.1$ & 0,776 & 0,724 & Valid \\
\hline usefulness & X3.2 & 0,896 & & Nilai KMO dan skor \\
\hline \multirow[t]{4}{*}{$\left(\mathrm{X}_{3}\right)$} & X3.3 & 0,856 & & factor loading $>0,5$ \\
\hline & X3.4 & 0,855 & & \\
\hline & X3.5 & 0,884 & & \\
\hline & X3.6 & 0,879 & & \\
\hline Kepuasan & Y.1 & 0,639 & 0,652 & Valid \\
\hline pengguna & Y.2 & 0,605 & & Nilai KMO dan skor \\
\hline akhir & Y.3 & 0,680 & & factor loading $>0,5$ \\
\hline \multirow[t]{2}{*}{$(\mathrm{Y})$} & Y.4 & 0,569 & & \\
\hline & Y.5 & 0,779 & & \\
\hline
\end{tabular}

Sumber : Data diolah, 2020

Berdasarkan tabel diatas dapat diketahui nilai KMO (Kaiser-Meyer-Olkin Measure of Sampling Adequacy) masing-masing variabel minimal 0,5 sesuai dengan ketentuan indikator validitas menggunakan analisis faktor. Korelasi anti image menghasilkan korelasi yang cukup tinggi untuk masing-masing item yaitu lebih dari atau sama dengan 0,5 sehingga dapat 
dinyatakan bahwa semua indikator yang digunakan dalampenelitian ini memenuhi kriteria sebagai pembentuk construct dan penelitian dapat dilanjutkan.

\section{Hasil Uji Reliabilitas Instrumen Penelitian}

Pada penelitian ini digunakan teknik perhitungan reliabilitas koefisien Alpha Cronbach, dengan alasan komputasi dengan teknik ini akan memberikan harga yang lebih kecil atau sama besar dengan reliabilitas yang sebenarnya (Azwar, 2017). Nilai batas yang digunakan untuk menilai tingkat reliabilitas yang dapat diterima adalah 0,60 (Ghozali, 2013). Hasil pengujian reliabilitas variabel penelitian dapat dilihat pada Tabel berikut ini.

Tabel 4. Hasil Uji Reliabilitas Instrumen Penelitian

\begin{tabular}{ccc}
\hline \multicolumn{1}{c}{ Variabel } & Nilai Cronbach Alpha & Keterangan \\
\hline Kualitas sistem informasi & 0,621 & Reliabel \\
\hline Kualitas informasi & 0,652 & Reliabel \\
\hline Perceived usefulness & 0,664 & Reliabel \\
\hline Kepuasan pengguna akhir & 0,650 & Reliabel \\
\hline Sumber : Data diolah, 2020 & &
\end{tabular}

Berdasarkan hasil analisis data sebagaimana ditunjukkan pada tabel ini diketahui bahwa seluruh koefisien Alpha Cronbach variabel penelitian lebih besar dari nilai 0,6; yang berarti bahwa seluruh instrumen penelitian adalah reliabel (handal)

\section{Hasil Uji Normalitas}

Uji normalitas yang dilakukan dalam penelitian adalah dengan melakukan uji Kolmogorov-Smirnov. Data-data yang berdistribusi normal memiliki nilai probabilitas $>0,05$ (Ghozali, 2013). Hasil pengujian normalitas data dapat dilihat pada tabel berikut ini.

\section{Tabel 5. Hasil Uji Normalitas Data Penelitian}

\begin{tabular}{|c|l|c|c||}
\hline No & \multicolumn{1}{|c||}{ Variabel } & -value & Keterangan \\
\hline 1. & Kualitas Sistem Informasi & 0,177 & Normal \\
\hline 2. & Kualitas informasi & 0,152 & Normal \\
\hline 3. & Perceived usefulness & 0,094 & Normal \\
\hline 4. & Kepuasan pengguna akhir & 0,080 & Normal \\
\hline
\end{tabular}

Sumber: Data diolah, 2020

Berdasarkan Tabel diatas terlihat bahwa nilai probabilitas (Asymp. Sig.) masing-masing variabel > 0,05; dengan demikian disimpulkan bahwa data penelitian dapat dikatakan berdistribusi normal.

\section{Uji Multikolenieritas}

Hasil pengujian multikolenieritas dapat dilihat pada Tabel berikut ini.

Tabel 6Hasil Uji Multikolenieritas

\begin{tabular}{lccc}
\hline Variabel & Nilai VIF & Tolerance & Ket \\
\hline Kualitas sistem informasi & 1,148 & 0,871 & Bebas \\
\hline Kualitas informasi & 1,112 & 0,899 & Multikolenieritas \\
\hline Perceived usefulness & 1,035 & 0,866 & \\
\hline Sumber : Data diolah, 2020 & & &
\end{tabular}

Sumber : Data diolah, 2020

Pada Tabel diatas terlihat bahwa nilai VIF ketiga variabel $<10$ dan nilai Tolerance ketiga variabel $>0,1$. Dengan demikian disimpulkan bahwa kedua variabel tersebut bebas dari gejala multikolenieritas.

\section{Uji Heteroskedastisitas}

Hasil pengujian heterosekedastisitas adalah sebagai berikut. 


\section{Tabel 7. Hasil Pengujian Heteroskedastisitas Data Penelitian}

\begin{tabular}{lcc}
\hline Variabel & Sign. & Ket \\
\hline Kualitas sistem informasi & 0,142 & Bebas Heteroskedastisitas \\
\hline Kualitas informasi & 0,316 & Bebas Heteroskedastisitas \\
\hline Perceived usefulness & 0,846 & Bebas Heteroskedastisitas \\
Sumber : Data diolah, 2020 & &
\end{tabular}

Berdasarkan Tabel di atas, diketahui bahwa nilai probabilitas (Asymp.sig.) variabel lebih besar dari 0,05. Berdasarkan hasil tersebut, dapat disimpulkan bahwa semua variable yang digunakan dalam penelitian ini memiliki varian yang homogen (bebas heterosekedastisitas).

\section{Hasil Pengujian Regresi dan Hipotesis}

Model analisis multivariate yang digunkan dalam penelitian ini adalah analisis regresi linier berganda. Variabel independen dalam penelitian ini adalah kualitas sistem informasi, kualitas informasi dan perceived usefulness:

Tabel 8. Hasil Analisis Regresi dan Pengujian Hipotesis

\begin{tabular}{|c|c|c|c|c|c|c|}
\hline Variabel & Koef & $\begin{array}{l}\text { Nilai } \\
\text { Koef }\end{array}$ & $\begin{array}{l}\text { Standard } \\
\text { Error }\end{array}$ & t-test & Sig. & Keterangan \\
\hline \multicolumn{7}{|c|}{ Persamaan : $Y=\alpha+\beta_{1} X_{1}+\beta_{2} X_{2}+\beta_{3} X_{3}+e$} \\
\hline $\begin{array}{l}\text { Kualitas sistem } \\
\text { informasi }\end{array}$ & $\beta_{1}$ & 0,280 & 0,066 & 3,200 & 0,002 & Diterima \\
\hline Kualitas informasi & $\beta_{2}$ & 0,178 & 0,068 & 2,064 & 0,041 & Diterima \\
\hline Perceived usefulness & $\mathrm{B}_{3}$ & 0,348 & 0,079 & 4,183 & 0,000 & Diterima \\
\hline
\end{tabular}

Dari tabel diatas diketahui bahwa nilai t-hitung variabel kualitas sistem informasisebesar 3,200dengan probabilitas (signifikansi) sebesar 0,002. Hasil tersebut menyimpulkan bahwa kualitas sistem informasiberpengaruh secara signifikan terhadap kepuasan pengguna akhir(karena nilai sig. $0,002<0,05$ ). Sedangkan nilai koefisien regresi yang diperoleh sebesar 0,280yang berarti bahwa pengaruh kualitas sistem informasiterhadap kepuasan pengguna akhir adalah positif. Hal ini berarti jika Aplikasi LAS mampu meningkatkan kapasitas pemrosesan data, memiliki sistem security yang tinggi, memiliki fasilitas mengkoreksi data maka tingkat kepuasan pengguna akhirsoftware analisis kredit pada PT. Bank Rakyat Indonesia, Tbk Cabang Bengkulu. Dengan demikian disimpulkan bahwa hipotesis pertama $\left(\mathrm{H}_{1}\right)$ dapat diterima.

Dari tabel diatas diketahui bahwa nilai t-hitung variabel kualitas informasisebesar 2,064dengan probabilitas (signifikansi) sebesar 0,041. Hasil tersebut menyimpulkan bahwa kualitas informasiberpengaruh secara signifikan terhadap kepuasan pengguna akhir (karena nilai sig. $0,041<0,05)$. Sedangkan nilai koefisien regresi yang diperoleh sebesar 0,178 yang berarti bahwa pengaruh kualitas sistem informasi terhadap kepuasan pengguna akhir adalah positif. Hal ini menggambarkan bahwa informasi aplikasi LAS sangat akurtat, hasil aplikasi LAS dapat dipercaya dan mudah dipahami akan meningkatkan kepuasan pengguna akhirsoftware analisis kredit pada PT. Bank Rakyat Indonesia, Tbk Cabang Bengkulu.Dengan demikian disimpulkan bahwa hipotesis kedua $\left(\mathrm{H}_{2}\right)$ dapat diterima.

Dari tabel diatas diketahui bahwa nilai t-hitung variabel perceived usefulness sebesar 4,183 dengan probabilitas (signifikansi) sebesar 0,000. Hasil tersebut menyimpulkan bahwa perceived usefulness berpengaruh secara signifikan terhadap kepuasan pengguna akhir (karena nilai sig. $0,000<0,05)$. Sedangkan nilai koefisien regresi yang diperoleh sebesar 0,348 yang berarti bahwa pengaruh perceived usefulness terhadap kepuasan pengguna akhir adalah positif. Hal ini menggambarkan bahwa aplikasi LAS sangat membantu dalam menyelesaikan analisis secara cepat, aplikasi LAS mampu meningkatkan efektivitas kerja dan aplikasi LAS mempermudah karyawan dalam menyelesaikan pekerjaan sehingga mampu meningkatkan 
kepuasan pengguna akhir software analisis kredit pada PT. Bank Rakyat Indonesia, Tbk Cabang Bengkulu. Dengan demikian disimpulkan bahwa hipotesis ketiga $\left(\mathrm{H}_{3}\right)$ dapat diterima.

\section{Pembahasan}

\section{Pengaruh Kualitas Sistem Informasi Terhadap Kepuasan Pengguna Akhir}

Berdasarkan hasil analisis data dan pengujian hipotesis diketahui bahwa variabel kualitas sistem informasi memiliki pengaruh yang signifikan terhadap kepuasan pengguna akhir software analisis kredit pada PT. Bank Rakyat Indonesia, Tbk Cabang Bengkulu. Hasil ini berarti bahwa semakian meningkat kualitas sistem informasi maka kepuasan pengguna akhir software analisis kredit pada PT. Bank Rakyat Indonesia, Tbk Cabang Bengkulu juga akan meningkat.Berdasarkan data statistik deskriptif jawaban responden, rata-rata jawaban responden untuk kualitas sistem informasi lebih tinggi dibandingkan rata-rata teoritis yang artinya kualitas sistem informasi dari aplikasi LAS (Loan Approval Sistem) sangat membantu karyawan dalam bekerja. Atas dasar hasil pengujian hipotesis 1 dan deskriptif aktual jawaban responden, maka dapat disimpulkan bahwa khusus pada penelitian ini, kualitas sistem informasi software analisis kredit yang ada pada PT. Bank Rakyat Indonesia, Tbk Cabang Bengkulu sudah baik sehingga dapat memberikan kepuasan kepada pengguna software tersebut karena dapat meringkan pekerjaan.

Hasil penelitian ini sejalan dengan teori Livari (2005) menyatakan bahwa semakin tinggi kualitas sistem indormasi dipahami oleh pemakai maka semakin sering mereka menggunakan sistem tersebut dan semakin puas mereka terhadap sistem. Pemakai sistem dalam meningkatkan kinerjanya mengharapkan sebuah sistem yang berkualitas untuk memanfaatkan sistem tersebut. Kualitas sistem informasi yang dirasakan oleh karyawan pengguna aplikasi LAS (Loan Approval Sistem) akan mempengaruhi penggunaan terhadap sebuah sistem. Semakin tinggi kualitas yang dirasakan maka semakin sering karyawan menggunakan sistem tersebut sehingga akan memberikan kepuasan bagi mereka yang pada akhirnya akan berdampak pada kinerja sistem itu sendiri Kepuasan pengguna sistem informasi merupakan salah satu tolok ukur keberhasilan sistem informasi akuntansi. Hal ini didasarkan pada teori nilai harapan yang dikembangkan oleh Ajzen dan Fishbein dalam Chai et al (2004). Menurut teori ini, variabel eksternal mempengaruhi keyakinan tentang hasil yang dihubungkan dengan perilaku yang dilakukan yang dilain pihak membentuk sikap terhadap perilaku yang dibentuk. Dalam penelitian ini bahwa software yang digunakan mempunyai banyak fasilitas, dapat mengoreksi maupun mengidentifikasi kesalahan dan software yang digunakan juga bersifat akurat sehingga pengguna software dapat menghasilkan laporan yang tepat dibutuhkan oleh pengguna sehingga pengguna merasa puas dengan software yang digunakan. Hasil penelitian ini sejalan dengan penelitian DeLone and McLean (1992), McKiney et al, (2002), Rai et al., (2002), McGill et al., (2003), Almutairi dan Subramanian (2005) dan Istianingsih dan Wijanto (2008).

\section{Pengaruh Kualitas Informasi Terhadap Kepuasan Pengguna Akhir}

Berdasarkan hasil analisis data dan pengujian hipotesis diketahui bahwa variabel kualitas informasi memiliki pengaruh terhadap kepuasan pengguna akhir software analisis kredit pada PT. Bank Rakyat Indonesia, Tbk Cabang Bengkulu. Artinya semakin meningkat kuaitas informasi dari software analisis kredit pada PT. Bank Rakyat Indonesia, Tbk Cabang Bengkulu maka akan meningkatkan kepuasan pengguna karena dengan adanya software LAS maka analisis kredit yang dilakukan dapat menghasilan data yang akurat, terpercaya, tepat waktu dan relevan. Berdasarkan rata-rata jawaban responden untuk variabel kualitas informasi mendekati rata-rata teoritis yang artinya para responden merasakan manfaat dari aplikasi kredit atau LAS yang mereka gunakan, karena dengan menggunakan aplikasi LAS dapat memberikan data yang akurat, tepat dan relevan. Atas dasar hasil pegujian hipotesis 2 dan deskriptif aktual jawaban responden maka dapat disimpulkan bahwa kualitas informasi yang bagus akan memberikan 
kepuasan taerhadap pengguna aplikasi LAS. Dengan demikian kualitas informasi terpengaruh terhadap kepuasan pengguna akhir pada PT. Bank Rakyat Indonesia, Tbk Cabang Bengkulu.

Hasil ini sejalan dengan teori DeLone \& McLean (1992) dalam Tumarni (2009) menjelaskan bahwa kualitas informasi harus memenuhi keandalan sehingga dapat memuaskan pengguna. Perilaku pengguna sistem informasi akan mempengaruhi penggunaan teknologi. Kualitas sistem informasi dapat diukur dengan ease of use (kemudahan penggunaan); response time (kecepatan akses), reliability (keandalan sistem), flexibility (fleksibilitas) dan security (keamanan). Semakin tinggi kualitas sistem dipahami oleh pemakai maka semakin sering mereka menggunakan sistem tersebut dan semakin puas mereka terhadap sistem. Pemakai sistem dalam meningkatkan kinerjanya mengharapkan sebuah sistem yang berkualitas untuk memanfaatkan sistem tersebut. Kualitas informasi dapat digunakan untuk mengukur kualitas keluaran dari sistem informasi. Kualitas informasi berupa dokumen operasional laporan yang terstruktur yang memiliki beberapa karakteristik sebagai berikut: relevan; tepat waktu; akurasi; kelengkapan; ringkas. Kualitas informasi merupakan model pengukuran yang berfokus pada keluaran yang diproduksi oleh sistem, serta nilai dari keluaran bagi pengguna

Hasil penelitian ini sesuai dengan hasil penelitian terdahulu seperti penelitian Tumarni (2009), Setyo dan Rahmawati (2015) serta Sudarmadi (2010) membuktikan bahwa kualitas informasi berpengaruh positif terhadap kepuasan pengguna sistem informasi..

\section{Pengaruh Perceived Usefulness Terhadap Kepuasan Pengguna Akhir}

Berdasarkan hasil analisis data dan pengujian hipotesis diketahui bahwa variabel perceived usefulness memiliki pengaruh terhadap kepuasan pengguna akhir software analisis kredit pada PT. Bank Rakyat Indonesia, Tbk Cabang Bengkulu. Hal ini menjelaskan bahwa hipotesis yang menyatakan perceived usefulness berpengaruh terhadap kepuasan pengguna akhir terbukti. Hal ini dikarenakan Aplikasi LAS dapat menyelesaikan tugas dengan cepat, dapat meningkatkan efektivitas dalam penyelesaian tugas dan sangat bermanfaat dalam melakukan analisis kredit. Berdasarkan data statistik deskriptif jawaban responden untuk perceived usefulness menunjukkan bahwa rata-rata jawaban responden untuk perceived usefulness lebih tinggi dibandingkan rata-rata teoritis yang artinya para responden menggagap bahwa perceived usefulness mampu meningaktkan kepuasan karyawan. Atas dasar hasil pengujian hipotesis dan deskriptif jawaban responden maka dapat dilihat bahwa perceived usefulness akan meningkatkan kepuasan pengguna akhir. Jadi dapat disimpulkan bahwa perceived usefulness berpengaruh terhadap kepuasan pengguna akhir.Hasil penelitian ini sejalan dengan teori dari Jogiyanto (2007), Perceived usefulness merupakan suatu kepercayaan tentang proses pengambilan keputusan, jika seseorang merasa percaya bahwa sistem informasi berguna maka dia akan menggunakannya. Sebaliknya jika seseorang merasa percaya bahwa sistem informasi kurang berguna maka dia tidak akan menggunakannya. Sehingga dari definisi tersebut dapat diartikan bahwa kemanfaatan dari penggunaan komputer dapat meningkatkan kinerja, dan prestasi kerja orang yang menggunakannya.

Perceived usefulness didefinisikan sebagai sejauh mana seseorang percaya bahwa menggunakan suatu teknologi akan bermanfaat meningkatkan kinerja pekerjaannya. Perceived usefulness menjadi ukuran kepercayaan jika suatu teknologi informasi tersebut memberikan banyak manfaat bagi penggunanya. Apabila pengguna sistem informasi mempercayai bahwa sistem informasi yang digunakannya bermanfaat, maka pengguna akan merasa puas dan menggunakan sistem informasi tersebut secara terus menerus. Sebaliknya, jika pengguna sistem informasi percaya bahwa sistem informasi kurang berguna maka akan menimbulkan sikap enggan dalam menggunakan sistem tersebut.Hal ini menjelaskan bahwa pengguna sistem informasi merasa puas pada tingkat akurasi informasi yang dihasilkan ketimbang produktivitas pemakai, pengguna sistem informasi merasa puas melihat isi informasi yang memadai ketimbang peningkatan kinerja, dan pengguna sistem informasi merasa puas pada penggunaan aplikasi yang baik ketimbang waktu untuk menyelesaikan tugas dan pada akhirnya tidak 
memberikan kepuasan bagi pengguna system informasi serta terdapat faktor lain yaitu fitur aplikasi belum lengkap sehingga manfaat yang diperoleh belum maksimal dan berdampak pada tingkat kepuasan pengguna sistem informasi rendah.

Hasil penelitian ini sejalan dengan penelitian DeLone and McLean (1992), Seddon (1997), Livari (2005), Istianingsih dan Wijanto (2008) yang menyatakan bahwa Perceived Usefulness berpengaruh positif terhadap kepuasan pengguna. Hal ini menunjukkan bahwa semakin tinggi Perceived Usefulness akan semakin meningkatkan kepuasan pengguna dan pengguna merasa puas pada penggunaan software akutansi yang menghasilkan laporan sesuai dengan yang dibutuhkan oleh pengguna sehingga dengan informasi yang dihasilkan sesuai dengan dibutuhkan maka akan dapat meningkatkan produktivitas kerja pengguna.

\section{SIMPULAN DAN SARAN}

Berdasarkan hasil penelitian bahwa pengguna akhir atau mantri pada PT. Bank Rakyat Indonesia, Tbk Cabang Bengkulu merasa puas menggunakan aplikasi LAS dalam menganalisis kredit karena aplikasi LAS telah mampumeningkatkan kapasitas pemrosesan data secara cepat. Pengguna akhir juga merasa aman karena aplikasi LAS memiliki tingkat keamanan sistem yang tinggi sehingga kerahasiaan data nasabah akan terjamin. Aplikasi LAS pada PT. Bank Rakyat Indonesia, Tbk Cabang Bengkulu dapat membantu pengguna akhir dalam menghasilkan data analisis kredit yang akurat, terpercaya, tepat waktu dan relevan. Hal ini menggambarkan sistem informasi yang dihasilkan oleh Aplikasi LAS memberikan hasil yang maksimal dalam melakukan analsiis kredit sehingga mempercepat tugas dari mantri dalam menganalisis kredit. Aplikasi LAS yang digunakan oleh PT. Bank Rakyat Indonesia, Tbk Cabang Bengkulu mampu meningkatkan efektivitas kerja dan memberikan kemudahan kepada pengguna yaitu mantri dalam melakukan analisis kredit pinjaman nasabah.

Keterbatasan dalam penelitian ini adalah Data dalam penelitian ini hanya dapat dikumpulkan dari responden yang ada pada 17 unit PT. Bank Rakyat Indonesia, Tbk Cabang Bengkulu. Seharusnya peneliti dapat mengumpulka data dari keseluruhan responden yang ada diseluruh PT. Bank Rakyat Indonesia, Tbk Cabang Bengkulu. Keterbatasan ini dikarenakan pengguna aplikasi digunakan oleh karyawan outsorsing dan bukan karyawan tetap sehingga tidak termasuk kedalam kriteria penilaian. Penelitian ini menggunakan obyek penelitian yang kurang luas, yaitu PT. Bank Rakyat Indonesia, Tbk Cabang Bengkulu. Kondisi ini dapat diartikan bahwa hasil penelitian ini belum bisa digeneralisasikan bagi penelitian dengan obyek yang sama

Peneliti selanjutnya hendaknya meneliti pada PT. Bank Rakyat Indonesia, Tbk di Provinsi Bengkulu, tidak hanya di kota Bengkulu melainkan di kota lain yang menggunaan aplikasi yang sama. Jumlah sampel yang dipakai dianggap terlalu kecil dan hanya berada dalam satu lingkup yang terbatas, untuk penelitian selanjutnya disarankan untuk menggunakan sampel yang lebih luas dan tidak hanya di PT. Bank Rakyat Indonesia, Tbk Cabang Bengkulu, sehingga hasil penelitian dapat digeneralisasi. 


\section{DAFTAR PUSTAKA}

Ajzen, I. (1991). The theory of planned behavior. Organizational Behavior and Human Decision Processes, 50, 179-211

Arikunto, S. (2012). Prosedur Penelitian: Suatu Pendekatan Praktek. Jakarta: Rineka Cipta Chin, Wynne. W., and Todd, Peter, A., (1995), "On the Use, Usefulness, and Ease of Use A Structural Equation Modeling in MIS Research: A Note of Caution”, MIS Quarterly, June.

Davis, Fred D., (1989), Perceived Usefulness, Perceived Ease of Use, and User Acceptance of Information Technology, MIS Quarterly, September, pp.319- 340

Davis, Fred D., Bagozzi, Richard P., dan Paul R.W (1989). User Acceptance Of Computer Technology: A Comparison Two Theoretical Models. Management Science, Vol.35/8/1989.

DeLone, W.H., and Ephraim R. Mclean, (2003), "Information System Success: The Quest for the Dependent Variable”. Information System Research, March, 60-95.

Ghozali, Imam, 2011. Aplikasi Analisis Multivariate Dengan Program SPSS, Edisi Keempat, Penerbit Universitas Diponegoro.

Goodhue, D.I dan Thompson. R. L. (2005). “Task -Technology and Individual Performance”. Mis Quarterly, Juni 213-236.

Hair et al., (1998), Multivariate Data Analysis, Fifth Edition, Prentice Hall, Upper Saddle River : New Jersy

Ives, B., Olson, M.H., and Baroudi, J. (1983). "The Measurement of User Information Satisfaction". Communications of The ACM. (26)10 (October) pp. 785-793.

Janson, M. A., and Subramanian, A., (1996), "Packaged software: Selection and Implementation Policies".INFOR, (34)2, 133-151.

Jogiyanto. (2007). Model Kesuksesan Sistem Informasi Teknologi. Yogyakarta: PenerbitAndi.

Liu, C., and Arnett, K.P. (2010). Exploring the factors associated with website success in the context of electronic commerce. Information and Management, 38, 23- 33

Lucas, H.C., Jr., Walton, E.J., \& Ginzberg, M.J. 1988.’Implementing Packaged Software”, MIS Quarterly, (12) 4, 537 -549.

Mulyadi.2013. Sistem Informasi Akuntansi. Jakarta: Salemba Empat.

Mulyanto. Agus. (2009). Sistem Informasi Konsep dan Aplikasi. Pustaka Pelajar. Yogyakarta O’Brien, James A. (2009). Pengantar Sistem Informasi.Jakarta:Salemba Empat.

Pamungkas, Fradela Aji (2017) Pengaruh Kualitas Sistem Informasi, Kualitas Informasi, Dan Perceived Usefulness Terhadap Kepuasan Pengguna Akhir Software Akuntansi (Studi Empiris Pada Perusahaan Yang Menggunakan Sistem Erp). Jurnal Fakultas Ekonomi dan Bisinis Universitas Muhammadiyah Surakarta

Rai, A., Lang, S.S. and Welker, R.B. 2012. Assessing the Validity of IS Success Models: An Empirical Test and Theoretical Analysis, Information System Research. Vol.13, No.1. pp. 29-34.

Rukmiyati, Ni Made Sri. (2016). Pengaruh Kualitas Sistem Informasi, Kualitas Informasi Dan Perceived Usefulness Pada Kepuasan Pengguna Akhir Software Akuntansi (Studi Empiris Pada Hotel Berbintang Di Provinsi Bali). E-Jurnal Ekonomi dan Bisnis Universitas Udayana (5)1: 115-142. ISSN : 2337-3067

Salam. Muhammad. Arqam. (2016). Pengaruh Kualitas Sistem Informasi, Kualitas Informasi, Perceived Usefulness Terhadap Kepuasan Pengguna Sistem Informasi Akuntansi. Jurnal Fakultas Ekonomi dan Bisnis Universitas Hasanuddin Makasar

Sarosa, Samiaji. (2009). Sistem Informasi Akuntansi, Grasindo, Jakarta.

Sugiyono, (2013). Statistika Untuk Penelitian. Cetakan keenam, Penerbit Alfabeta, Bandung. 
Thompson, Ronald L., Higgins, Christoper A., dan Howell, Jane M., (1991), Personal Computing: Toward a Conceptual Model of Utilization, MIS Quarterly, March, pp.125-143.

Umar, Husein, (2008), Desain Penelitian MSDM dan Perilaku Karyawan, Seri Desain Penelitian Bisnis - No 1, PT Rajagrafindo Persada Jakarta

Widjayanto, Nugroho, (2001), Sistem Informasi Akuntansi, Penerbit Erlangga 